\title{
Cytotoxic sesquiterpene lactones from the aerial parts of Inula aucheriana
}

\author{
AHMAD REZA GOHARI ${ }^{1}$, MAHMOUD MOSADDEGH ${ }^{2}$, FARZANEH NAGHIBI ${ }^{2}$, \\ BAHARA ESLAMI-TEHRANI ${ }^{2}$, ATEFEH PIRANI ${ }^{2}$, \\ MARYAM HAMZELOO-MOGHADAM ${ }^{3}$ and ROGER W. READ ${ }^{4}$ \\ ${ }^{1}$ Medicinal Plants Research Center, Faculty of Pharmacy, \\ Tehran University of Medical Sciences, 1516745811, Tehran, Iran \\ ${ }^{2}$ Traditional Medicine and Materia Medica Research Center, \\ Shahid Beheshti University of Medical Sciences, 1516745811, Tehran, Iran \\ ${ }^{3}$ Department of Traditional Pharmacy, School of Traditional Medicine, \\ Shahid Beheshti University of Medical Sciences, 1516745811, Tehran, Iran \\ ${ }^{4}$ School of Chemistry, University of New South Wales, UNSW Sydney 2052 NSW, Australia \\ Manuscript received on February 13, 2014; accepted for publication on October 24, 2014
}

\begin{abstract}
Inula aucheriana $\mathrm{DC}$ is a member of the family Asteraceae which is known to produce cytotoxic secondary metabolites noted as sesquiterpene lactones. In the present study, sesquiterpene lactones inuchinenolide B, 6-deoxychamissonolide (stevin) and 14-acetoxy-1 $\beta, 5 \alpha, 7 \alpha \mathrm{H}-4 \beta$-hydroxy-guai-9(10),11(13)-dien-12,8 $\alpha$ olide were isolated from I. aucheriana. Inuchinenolide B and 14-acetoxy- $1 \beta, 5 \alpha, 7 \alpha \mathrm{H}-4 \beta$-hydroxy-guai9(10),11(13)-dien-12,8 $\alpha$-olide were further evaluated by the MTT (3-(4,5-dimethylthiazol-2-yl)-2,5diphenyl tetrazolium bromide) assay to demonstrate cytotoxic activity with $\mathrm{IC}_{50}$ values of $(56.6,19.0)$, $(39.0,11.8)$, and $(55.7,15.3) \mu \mathrm{g} / \mathrm{mL}$ against HepG-2, MCF-7 and A-549 cells, respectively. The cytotoxic activity of the two evaluated sesquiterpene lactones partly explains the cytotoxic activity that was previously observed for the extracts of Inula aucheriana. The isolated compounds could be further investigated in cancer research studies.
\end{abstract}

Key words: cytotoxicity, Inula aucheriana, MTT assay, sesquiterpene lactones.

\section{INTRODUCTION}

Inula aucheriana DC. a perennial species of Asteraceae grows in the West Azerbaijan province, Iran. It is a member of the Inula genus which has about 100 species of mainly perennial and subshrubs, distributed across warm and temperate parts of Europe, Asia and Africa (Bown 2002). Some species

Correspondence to: Maryam Hamzeloo-Moghadam

E-mail:mhmoghadam@itmrc.org of this genus have been used in traditional medicine by Greek, Roman and Chinese healers for their expectorants, antitussives, diaphoretics, antiemetics, and antibacterial properties (Seca et al. 2014). Compounds like monoterpenes, sesquiterpenes, diterpenes, flavonoids, and glycolipids have been isolated from Inula while several biological effects like antiproliferative, antibacterial and hepatoprotective activity have been reported from this genus (Zhao 
et al. 2006). Some phytochemical studies about different species of Inula have introduced several cytotoxic and apoptotic compounds, most of these isolated materials are sesquiterpene lactones of different structure types. There has been limited research about the cytotoxicity of Inula aucheriana; however, our previous study demonstrated that the extracts from the aerial parts of this species exhibit cytotoxicity to several cancerous cell lines (Hamzeloo-Moghadam et al. 2012); thus the present study was focused on the isolation of compounds from the aerial parts of this Asteraceae species as well as on the evaluation of their cytotoxic activity to find the compound/ compounds that are at least partially responsible for the previously observed cytotoxic results.

\section{EXPERIMENTAL}

GENERAL EXPERIMENTAL PROCEDURES

IR (Infrared) spectra were recorded on a Nicolet Maga 550, and NMR spectra on a Bruker instrument, operating at $500 \mathrm{MHz}$ for ${ }^{1} \mathrm{H}$ and 125 $\mathrm{MHz}$ for ${ }^{13} \mathrm{C}$. TMS (Tetramethylsilane) was used as internal standard. HRMS (High Resolution Mass Spectroscopy) were obtained with an Orbitrap LTQ XL (Thermo Fisher Scientific, San Jose Ca, USA) ion trap mass spectrometer using a nanospray (nanoelectrospray) ionization source to generate ions from methanol solutions.

CHEMICALS AND REAGENTS

RPMI 1640 medium, penicillin-streptomycin, 3-(4,5-dimethylthiazol-2-yl)-2,5-diphenyl tetrazolium bromide (MTT) from Sigma, DMEM medium and FBS (Gibco). Organic solvents (analytical grade) were purchased from Merck.

Plant MATERIAL

Inula aucheriana was collected from the West Azerbaijan province, Iran (July 2010) and was authenticated by botanists of the Traditional Medicine and Materia Medica Research Center (TMRC), Shahid Beheshti University of Medical Sciences, Tehran, Iran. A voucher specimen was deposited at TMRC Herbarium for future reference (voucher no. TMRC 3173). The aerial parts of the species were dried in shade and ground for extraction.

\section{EXTRACTION AND ISOLATION}

Dried aerial parts of $I$. aucheriana $(500 \mathrm{~g})$ were successively extracted with $n$-hexane and chloroform (each solvent for 3 days), every day the solvent was replaced with fresh solvent to yield $n$-hexane $(9.4 \mathrm{~g})$ and chloroform (8.9 g) extracts. The chloroform extract (5 g) was subjected to Vacuum Liquid Chromatography [(VLC) silica gel, 40-63 Nm] using sequential washings with EtOAc, EtOAc - MeOH (2:1)-(1:1) and $\mathrm{MeOH}$ as eluent to give two fractions (F1-F2). Fraction F1 (1600 mg) was fractionated by silica gel SPE (7.5 $\times 2.5 \mathrm{~cm}, 40-63 \mu \mathrm{m})$ with $\mathrm{CH}_{2} \mathrm{Cl}_{2}, \mathrm{CH}_{2} \mathrm{Cl}_{2}$ - EtOAc (10:1)- (1:1), EtOAc , EtOAc- MeOH (3:1)-(1:1) and $\mathrm{MeOH}$ respectively, to afford 17 fractions (Fr1Fr17). Fraction Fr8 (139 mg) was further subjected to semi preparative HPLC (Shimadzu, SPD 20A :ODS, PDA detector) with water-acetonitrile $(75: 25)$ as the mobile phase and flow rate of $8 \mathrm{~mL} /$ min, to finally afford compound A ( $8 \mathrm{mg}, 0.0016 \%$ ), B (26 mg, 0.0052\%) and C (5 mg, 0.0010\%).

\section{PREPARATION FOR MTT ASSAY}

The compounds were dissolved in DMSO (5 $\mathrm{mg} / 500 \mu \mathrm{L})$. The final concentrations $(100 \mu \mathrm{g} / \mathrm{mL}$, $50 \mu \mathrm{g} / \mathrm{mL}, 25 \mu \mathrm{g} / \mathrm{mL}, 12.5 \mu \mathrm{g} / \mathrm{mL}, 6.25 \mu \mathrm{g} / \mathrm{mL}$ and $3.125 \mu \mathrm{g} / \mathrm{mL}$ ) were provided from the above solution (final DMSO concentration was 1\%).

\section{CELl Lines}

The human tumor cell lines were obtained from the Pasteur Institute, Tehran, Iran: HepG-2 (human hepatocellular carcinoma), MCF-7 (human breast adenocarcinoma), and A-549 (Non-small cell lung carcinoma). MCF-7 cells were cultured in DMEM 
medium with 5\% FBS, while the other two cell lines were maintained in RPMI 1640 medium with 10\% FBS to obtain the desired growth. All cell lines were treated with $1 \%$ penicillinstreptomycin, in a humidified incubator at $37^{\circ} \mathrm{C}$ in an atmosphere of $5 \% \mathrm{CO}_{2}$.

\section{MTT ASSAY}

The assessment of the viability of the cells was carried out in a micro culture tetrazolium/formazan assay (MTT assay) (Mosaddegh et al. 2006, 2010). Ninety six-well plates were used and HepG-2 cells $15 \times 10^{3}, \mathrm{MCF}-7$ cells $8 \times 10^{3}$ and A-549 cells 8 $\times 10^{3}$ were seeded in each well. They were then incubated at $37^{\circ} \mathrm{C}$. After $24 \mathrm{~h}$ the medium was replaced with fresh medium containing different concentrations of the compounds to be tested. After $72 \mathrm{~h}$ exposure of the cells at $37^{\circ} \mathrm{C}$ to each sample, the medium was replaced with fresh medium containing MTT, with a final concentration of $0.5 \mathrm{mg} / \mathrm{mL}$. The cells were incubated for another $4 \mathrm{~h}$ in a humidified atmosphere at $37^{\circ} \mathrm{C}$, then the medium containing MTT was removed and the remaining formazan crystals dissolved in DMSO. The absorbance was recorded at $570 \mathrm{~nm}$ with an ELISA reader (TECAN). Tamoxifen was used as positive control. The relative cell viability (\%) related to control wells containing cells, cell culture medium and DMSO 1\%, was calculated by $[\mathrm{A}]$ samples $/[\mathrm{A}]$ control $\times 100$ where $[\mathrm{A}]$ samples was the absorbance of test sample and [A]control was the absorbance of wells containing cells + medium+DMSO1\%. To calculate $\mathrm{IC}_{50}$, viability (\%) versus log concentrations was graphed by Microsoft Excel program, and the concentration at $50 \%$ viability was determined.

\section{RESULTS AND DISCUSSION}

Compounds A, B and C, reported for the first time from Inula aucheriana were identified as inuchinenolide B 1, 14-acetoxy- $1 \beta, 5 \alpha, 7 \alpha \mathrm{H}$ -

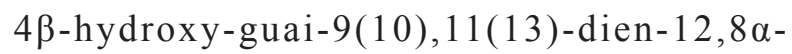
olide 2 (here named aucherinolide) and 6deoxychamissonolide 3 (Fig. 1), respectively.

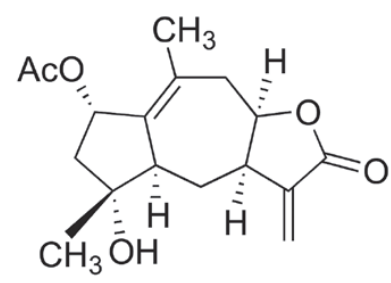

1

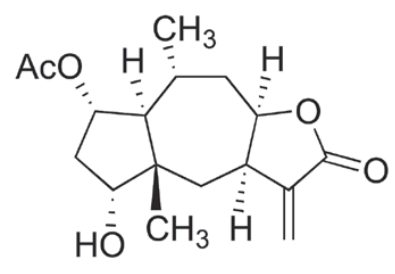

2

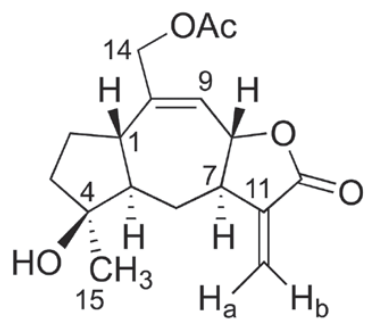

3

Figure 1 - Chemical structures of inuchinenolide B 1, aucherinolide 2 and 6-deoxychamissonolide 3.

Although they were known compounds (Ito and Iida 1981, Cheng et al. 2012, Willuhn et al. 1981), their 2D NMR data were not available in the literature, and for 6-deoxychamissonolide 2, the previously reported NMR spectra was obtained in acetone-D6, while those in this report were obtained in $\mathrm{CDCl}$. The $1 \mathrm{D}$ and 2D NMR data for inuchinenolide B and 6-deoxychamissonolide are reported in Table I. The molecular formulae of $\mathrm{C}_{17} \mathrm{H}_{22} \mathrm{O}_{5}$ for inuchinenolide B (m/z: 329.1357 $[\mathrm{M}+\mathrm{Na}]^{+}$) and $\mathrm{C}_{17} \mathrm{H}_{24} \mathrm{O}_{5}$ for 6-deoxychamissonolide $\left(\mathrm{m} / \mathrm{z}: 331.1515[\mathrm{M}+\mathrm{Na}]^{+}\right)$were revealed by highresolution QTOF mass spectrometric analysis.

Compound $\mathrm{B}$, which we name aucherinolide, was unusual. The molecular formula of $\mathrm{C}_{17} \mathrm{H}_{22} \mathrm{O}_{5}$ $\left(\mathrm{m} / \mathrm{z}: 345.1310[\mathrm{M}+\mathrm{K}]^{+}\right)$was obtained by highresolution QTOF mass spectrometry. The ${ }^{1} \mathrm{H}$ - and ${ }^{13} \mathrm{C}-\mathrm{NMR}$ spectra and the key HMBC correlations 
TABLE I

${ }^{1} \mathrm{H}$ and ${ }^{13} \mathrm{C}$ NMR chemical shifts $(\delta, \mathrm{ppm}),{ }^{1} \mathrm{H}$ multiplicities (mult.) and coupling constants $(\mathrm{J}, \mathrm{Hz}),{ }^{1} \mathrm{H}-{ }^{13} \mathrm{C}$ correlations in $\mathrm{HMBC}$ spectra and ${ }^{1} \mathrm{H}-$ ${ }^{1} \mathrm{H}$ correlations for compounds $\mathrm{A}$ and $\mathrm{C}$ in $\mathrm{CDCl3}$.

\begin{tabular}{|c|c|c|c|c|c|c|c|c|}
\hline No. & & $\mathbf{A}$ & & & & & & \\
\hline & $\delta_{\mathrm{H}}($ mult, $J / \mathrm{Hz})$ & $\delta_{\mathrm{C}}$ & COSY & HMBC & $\delta_{\mathrm{H}}($ mult, $J / \mathrm{Hz})$ & $\delta_{\mathrm{C}}$ & COSY & HMBC \\
\hline 1 & - & 135.8 & - & - & $1.86(\mathrm{~m})$ & 52.8 & $\mathrm{H}-2$ & C- 2,15 \\
\hline 2 & $5.46(\mathrm{t}, 7.6)$ & 72 & $\mathrm{H}-3 \mathrm{a}, \mathrm{b}$ & C- $1,10,17$ & $4.93(\mathrm{tw}, 7.8)$ & 74.9 & $\mathrm{H}-1$ & $\mathrm{C}-4,5,17$ \\
\hline $3 a$ & $1.72(\mathrm{dd}, 7.8, \mathrm{e} 12.6)$ & 46.9 & $\mathrm{H}-2$ & $\mathrm{C}-2,4,14$ & 1.84 & 38.4 & $\mathrm{H}-2,4$ & C- $4,7,9$ \\
\hline $3 b$ & $2.48(\mathrm{dd}, 7.6,12.6)$ & & $\mathrm{H}-2$ & C- $1,4,5,14$ & 2.06 & & $\mathrm{H}-2,4$ & C-2, 4, \\
\hline 4 & - & 77 & - & - & 4.04 & 80.6 & $\mathrm{H}-3$ & C-6, 15 \\
\hline 5 & $2.70($ brd, 11.5$)$ & 52.2 & H-6 & - & - & 27.1 & - & - \\
\hline $6 a$ & $1.48(\mathrm{~m})$ & 25 & H-5, 7 & $C-1,5,7$ & 1.41 & 38.0 & $\mathrm{H}-7$ & C- 1,15 \\
\hline $6 b$ & $2.26(\mathrm{~m})$ & & $\mathrm{H}-7$ & C-5, 7 & 2.33 & & $\mathrm{H}-7$ & $\mathrm{C}-7,8,15$ \\
\hline 7 & $3.3(\mathrm{~m})$ & 41.9 & $\mathrm{H}-8$ & - & 2.82 & 45.1 & H-8, 13 & - \\
\hline 8 & $4.88(\mathrm{~m})$ & 78.7 & H-9a, b & - & 4.24 & 81.4 & $\mathrm{H}-7,9$ & - \\
\hline $9 \mathrm{a}$ & $2.26(\mathrm{~m})$ & 36.6 & H-8 & C- $1,7,8,10,15$ & 1.40 & 44.0 & $\mathrm{H}-8$ & $\begin{array}{c}\mathrm{C}-7,8,9 \\
11,14\end{array}$ \\
\hline $9 b$ & $2.56(\mathrm{~m})$ & & $\mathrm{H}-8$ & - & 2.37 & & $\mathrm{H}-8$ & - \\
\hline 10 & - & 131.8 & - & - & 1.97 & 29.1 & $\mathrm{H}-1,9,14$ & - \\
\hline 11 & - & 138.3 & - & - & - & 140.4 & - & - \\
\hline 12 & - & 169.9 & - & - & - & 169.5 & - & - \\
\hline $13 \mathrm{a}$ & $5.64(\mathrm{~d}, 3.0)$ & 122 & $\mathrm{H}-7$ & C-7, 12 & 5.46 & 119.8 & H-7 & C-7, 12 \\
\hline $13 b$ & $6.32(\mathrm{~d}, 3.0)$ & & $\mathrm{H}-7$ & $\mathrm{C}-7,11,12$ & 6.18 & & $\mathrm{H}-7$ & $\mathrm{C}-7,11,12$ \\
\hline 14 & $1.05(\mathrm{~s})$ & 22.7 & - & $\mathrm{C}-3,4,5$ & 0.97 & 19.9 & - & $\mathrm{C}-1,9,10$ \\
\hline 15 & $1.66(\mathrm{~s})$ & 21.6 & - & C- $1,9,10$ & 0.93 & 18.7 & - & $C-1,4,6,7$ \\
\hline 16 & - & 170.7 & - & - & - & 170.5 & - & - \\
\hline 17 & $2.06(\mathrm{~s})$ & 20.9 & C-16 & - & 2.04 & 21.3 & - & C-17 \\
\hline
\end{tabular}

(Fig. 2) proved it to bea 12,8-guaianolide sesquiterpene lactone with an acetate group at $\mathrm{C}-14$. The structure was concluded as being 14 -acetoxy-1 $\beta, 5 \alpha, 7 \alpha \mathrm{H}-4 \beta$ hydroxy-guai-9(10),11(13)-dien- 12,8 $\alpha$-olide 2 (Fig. 1) based on this information and after comparison of the spectroscopic data with those of a new substance introduced by Cheng et al. (2012) for Inula hookeri. In particular, relative stereochemistry was able to be assigned by Cheng et al. (2012) through NOESY experiments. The NMR data are given in Table II and agree very closely with those of Cheng et al. (2012). The only exception is for the assigned proton chemical shift for $\mathrm{H}_{\mathrm{a}} 2$, for which we see clear correlation evidence for assignment at $\delta 1.78$, overlapped with the signal for $\mathrm{H}_{\mathrm{b}} 3$, and not at $\delta 1.40$, as reported.

There are several reports of cytotoxic and apoptotic sesquiterpene lactones from the genus Inula. A brief report follows. 1,6-O,O-diacetylbritannilactone

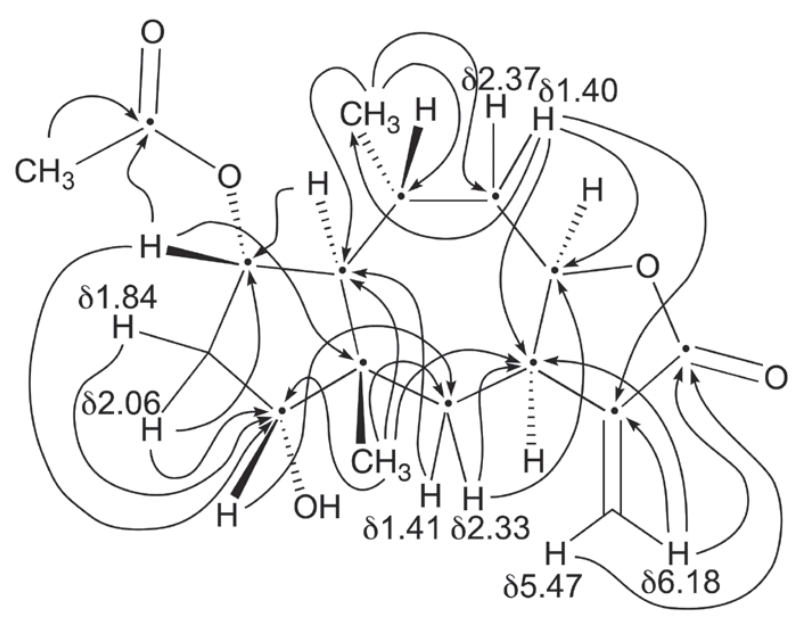

Figure 2 - Key HMBC correlations for aucherinolide.

from Inula britannica L. demonstrated strong cytotoxic activity and induction of apoptosis in HL-60 cells through the activation of caspase- $8,-9$, and -3 , phosphorylation of Bcl-2 and Bid, and by augmenting the 
TABLE II

${ }^{1} \mathrm{H}$ and ${ }^{13} \mathrm{C}$ NMR chemical shifts $(\delta, \mathrm{ppm}),{ }^{1} \mathrm{H}$ multiplicities (mult.) and coupling constants $(\mathrm{J}, \mathrm{Hz})$, ${ }^{1} \mathrm{H}-{ }^{13} \mathrm{C}$ correlations in $\mathrm{HMBC}$ spectra and ${ }^{1} \mathrm{H}-{ }^{1} \mathrm{H}$ correlations for compounds $\mathrm{A}$ and $\mathrm{C}$ in $\mathrm{CDCl}$.

\begin{tabular}{|c|c|c|c|c|}
\hline No. & & & B & \\
\hline & $\delta_{\mathrm{H}}(\mathrm{mult}, \mathrm{J} / \mathrm{Hz})$ & $\boldsymbol{\delta}_{\mathrm{C}}$ & COSY & НМВС \\
\hline 1 & $2.58^{*}(\mathrm{~m})$ & 45.0 & $\mathrm{H}-5$ & C-5, 9, 10/11 \\
\hline $2 a$ & $1.78(\mathrm{~m})$ & 23.7 & $\mathrm{H}-1,3$ & $\mathrm{C}-1 / 7,4,5$ \\
\hline $2 b$ & $1.88(\mathrm{~m})$ & & $\mathrm{H}-1,3$ & $\mathrm{C} 1 / 7,3,4,10$ \\
\hline $3 a$ & $1.67(\mathrm{~m})$ & 41.5 & $\mathrm{H}-2$ & $C-1,2,4,5$ \\
\hline $3 b$ & $1.80(\mathrm{~m})$ & & На-3 & C- $1,2,4$ \\
\hline 4 & - & 79.5 & - & - \\
\hline 5 & $1.63(\mathrm{~m})$ & 52.5 & H-1, 6 & C- $1 / 7,4,10$ \\
\hline $6 a$ & $1.43(\mathrm{~m})$ & 31.0 & $\mathrm{H}-5,7$ & C- $5,1 / 7,8$ \\
\hline $6 b$ & $2.50(\mathrm{~m})$ & & На- 6 & $\mathrm{C}-1 / 7$ \\
\hline 7 & $2.58^{*}(\mathrm{~m})$ & 45.2 & $\mathrm{H}-8, \mathrm{Hb}-13$ & C-5, 9, 10/11 \\
\hline 8 & $4.76(\mathrm{~d}, 9.3)$ & 81.7 & H-9 & $\mathrm{C}-1 / 7,6,9,10 / 11$ \\
\hline 9 & 6.15 (brs) & 129.9 & H-8, 14 & C- $1 / 7,14$ \\
\hline 10 & - & 138.6 & - & - \\
\hline 11 & - & 139.0 & - & - \\
\hline 12 & - & 169.9 & - & - \\
\hline $13 \mathrm{a}$ & $5.53(\mathrm{~d}, 2.8)$ & 119.7 & $\mathrm{H}-7$ & $\mathrm{C} 1 / 7,12$ \\
\hline $13 b$ & $6.21(\mathrm{~d}, 2.8)$ & & $\mathrm{H}-7$ & $\mathrm{C}-1 / 7,11,12$ \\
\hline 14 & $4.63(\mathrm{~s})$ & 65.5 & H-9 & C- $1 / 7,9,10,16$ \\
\hline 15 & $1.24(\mathrm{~s})$ & 31.4 & - & $\mathrm{C}-3,4,5$ \\
\hline 16 & - & 170.5 & - & - \\
\hline 17 & $2.10(\mathrm{~s})$ & 20.9 & - & C- 14,16 \\
\hline
\end{tabular}

release of cytochrome c from mitochondria (Pan et al. 2007). Acetylbritannilactone, also from Inula britannica, has enforced apoptosis in VSMC cells as shown by induction of a greater ratio of Bax/Bcl-2, activation of caspase-9, caspase-3, and the breakdown of Poly (ADP-ribose) polymerase (Liu et al. 2011). It has also hindered the growth via impelling cell cycle arrest in G0/G1 phase of HT-29 cancer cells (Fang et al. 2011). Eupatolide, another sesquiterpene from the same species has been shown to induce apoptosis in human breast cancer cells through tumor necrosis factorrelated apoptosis-inducing ligand (Lee et al. 2010). Ergolide has also been isolated from Inula britannica. Studies about the potential of this cytotoxic sesquiterpene lactone have proposed the mechanism for its inducing apoptosis through down regulation of cell survival signal molecules which occur as a consequence of inhibiting the NFkappaB signaling pathway (Song et al. 2005).

There has also been an effort to synthesize derivatives of Inula britannica sesquiterpene lactones through a study by Liu et al. (2005); derivatives of 1-O-acetylbritannilactone, (2- Oalkyloxime-3phenyl)-propionyl-1-O-acetylbritannilactone esters which are sesquiterpene lactones of the above mentioned species, have been synthesized and four of them have exhibited antiproliferative effects on HL-60 and Bel-7402 cell lines (Liu et al. 2005). Dimeric sesquiterpene lactones japonicones A-D have been previously isolated from Inula japonica Thunb., among which japonicone A has displayed the most potent cytotoxic activity on A-549, LOVO, CEM and MDA-MB-435 cells (Qin et al. 2009). Germacranolide inulacappolide from Inula cappa DC, has been evaluated for cytotoxicity and has shown strong activity against HeLa, K-562 and KB cell lines (Xie et al. 2007) and bigelovin isolated from Inula helianthus-aquatica has been cytotoxic to U937 cells and it has also instigated apoptosis and arrested the cell cycle at $\mathrm{G}(0) / \mathrm{G}(1)$ phase (Zeng et al. 2009). Pseudoguaianolides and guaianolides from Inula hookeri C. B. Clarke have been likewise investigated for antiproliferative activity on HepG-2, HeLa, PC3, and MGC-803 cell lines and have demonstrated cytotoxic results (Cheng et al. 2012). The sesquiterpene lactone isocostunolide from the roots of Inula helenium has strongly enforced cytotoxic activity in A-2058, HT-29, and HepG-2 cell lines. It has also been reported that isocostunolide could induce apoptosis in A-2058 cells via a mitochondriadependent pathway (Chen et al. 2007) and finally, gaillardin a sesquiterpene lactone isolated from the aerial parts of Inula oculus-christi has demonstrated cytotoxic activity and apoptotic induction in MCF-7 cells (Hamzeloo-Moghadam et al. 2013).

We have previously reported the apoptotic sesquiterpene lactone britannin from Inula aucheriana and in the present study three other 
sesquiterpene lactones have been isolated from the species. The amount of 6-deoxychamissonolide was not enough for biologic assay so the cytotoxic activities of inuchinenolide B and aucherinolide were evaluated and the results are shown in Figures 3-5 and Table III. Qin and colleagues have examined the cytotoxicity of inuchinenolide $\mathrm{B}$ in MCF-7 cells and have reported the $\mathrm{IC}_{50}$ value as $15.5 \mu \mathrm{M}$ (Qin et al. 2013); however, we have determined the $\mathrm{IC}_{50}$ value to be $39.0 \mu \mathrm{g} / \mathrm{mL}$ (118 $\mu \mathrm{M})$ in MCF-7 cells. The values were higher in
HepG-2 and A-549 cell lines but still revealed the cytotoxicity of the compound to these cells (56.6 $\mu \mathrm{g} / \mathrm{mL}$ equal to $172 \mu \mathrm{M})$ and $(55.7 \mu \mathrm{g} / \mathrm{mL}$ equal to $169 \mu \mathrm{M})$ in HepG-2 and A-549 cells, respectively. Aucherinolide demonstrated to be more potent in the above mentioned cells with $\mathrm{IC}_{50}$ values of $19.0 \mu \mathrm{g} / \mathrm{mL}(55 \mu \mathrm{M}), 15.3 \mu \mathrm{g} / \mathrm{mL}(44 \mu \mathrm{M})$ and $11.8 \mu \mathrm{g} / \mathrm{mL}(34 \mu \mathrm{M})$ in HepG-2, A-549 and MCF7 cells, respectively. The results could explain the previously reported cytotoxic results of Inula aucheriana extracts.

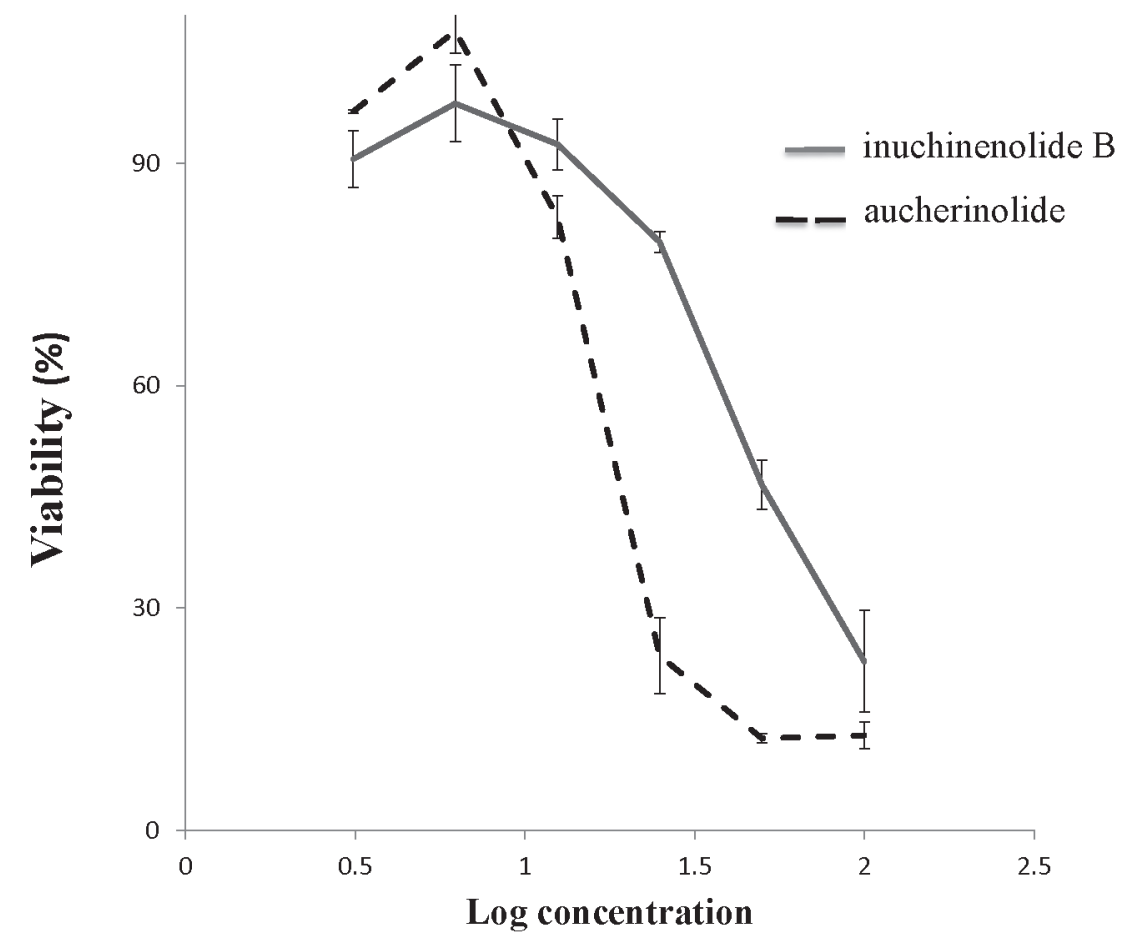

Figure 3 - Viability of inuchinenolide B and aucherinolide in HepG-2 cells. Values represent the mean $\pm \mathrm{SD}$ of 3 separate experiments.

Surveying the literature about the cytotoxicity of various sesquiterpene lactones which have been evaluated through MTT assay, reveals different ranges of $\mathrm{IC}_{50}$ for these compounds. Examples include deoxyelephantopin, a sesquiterpene lactone from Elephantopus scaber which has been evaluated in A-549 cell line to show cytotoxicity with $\mathrm{IC}_{50} 12.287 \mu \mathrm{g} / \mathrm{mL}$ (Kabeer et al. 2013). In another study, $\mathrm{IC}_{50}$ values of $6.37,6.20$ and 4.76 $\mu \mathrm{g} / \mathrm{mL}$ have been reported for sesquiterpene lactone gaillardin from the aerial parts of Inula oculuschristi in MCF-7, HepG-2 and A-549 cell lines, repectively (Hamzeloo-Moghadam et al. 2013), while sesquiterpene lactones from Laserpitium species have exhibited cytotoxicity with $\mathrm{IC}_{50}$ values of 4.32-97.54 $\mu \mathrm{M}$ against MCF 7/6 cell line (Popović et al. 2013). Moreover, Rosselli et al. (2012) have demonstrated $\mathrm{IC}_{50}$ values of 


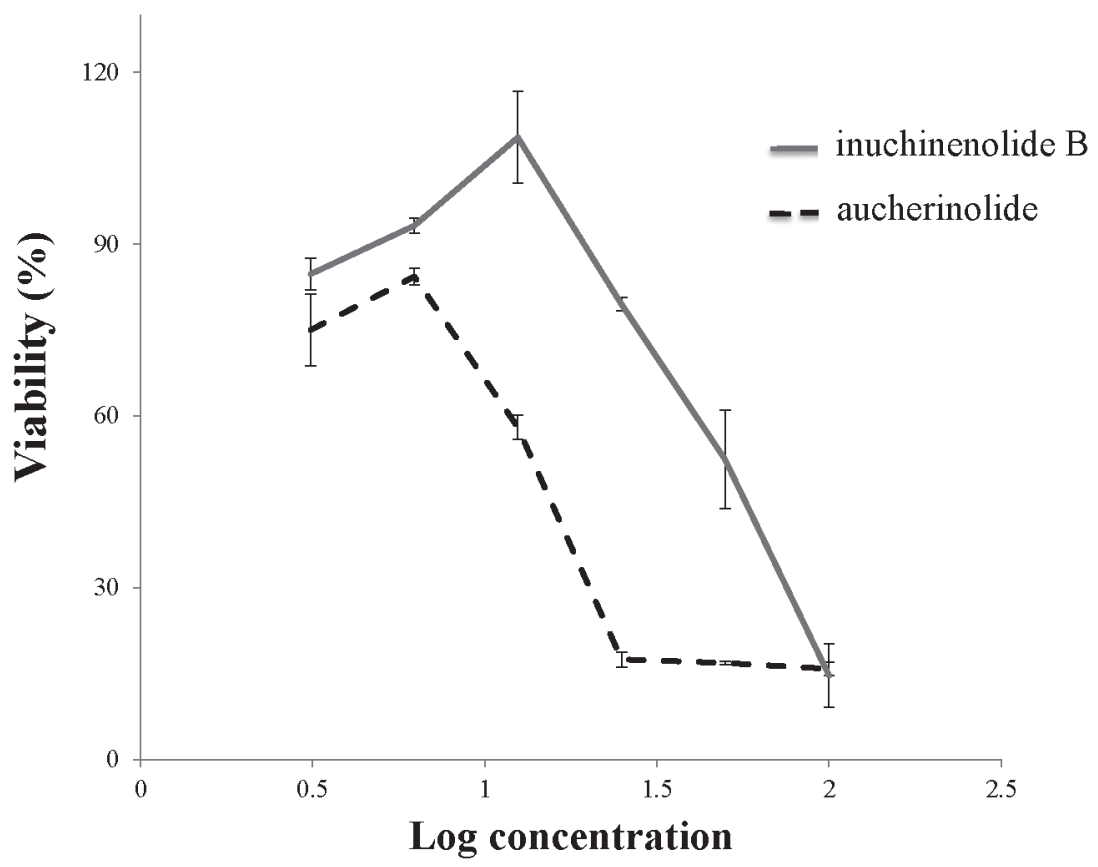

Figure 4 - Viability of inuchinenolide B and aucherinolide in A-549 cells. Values represent the mean $\pm \mathrm{SD}$ of 3 separate experiments.

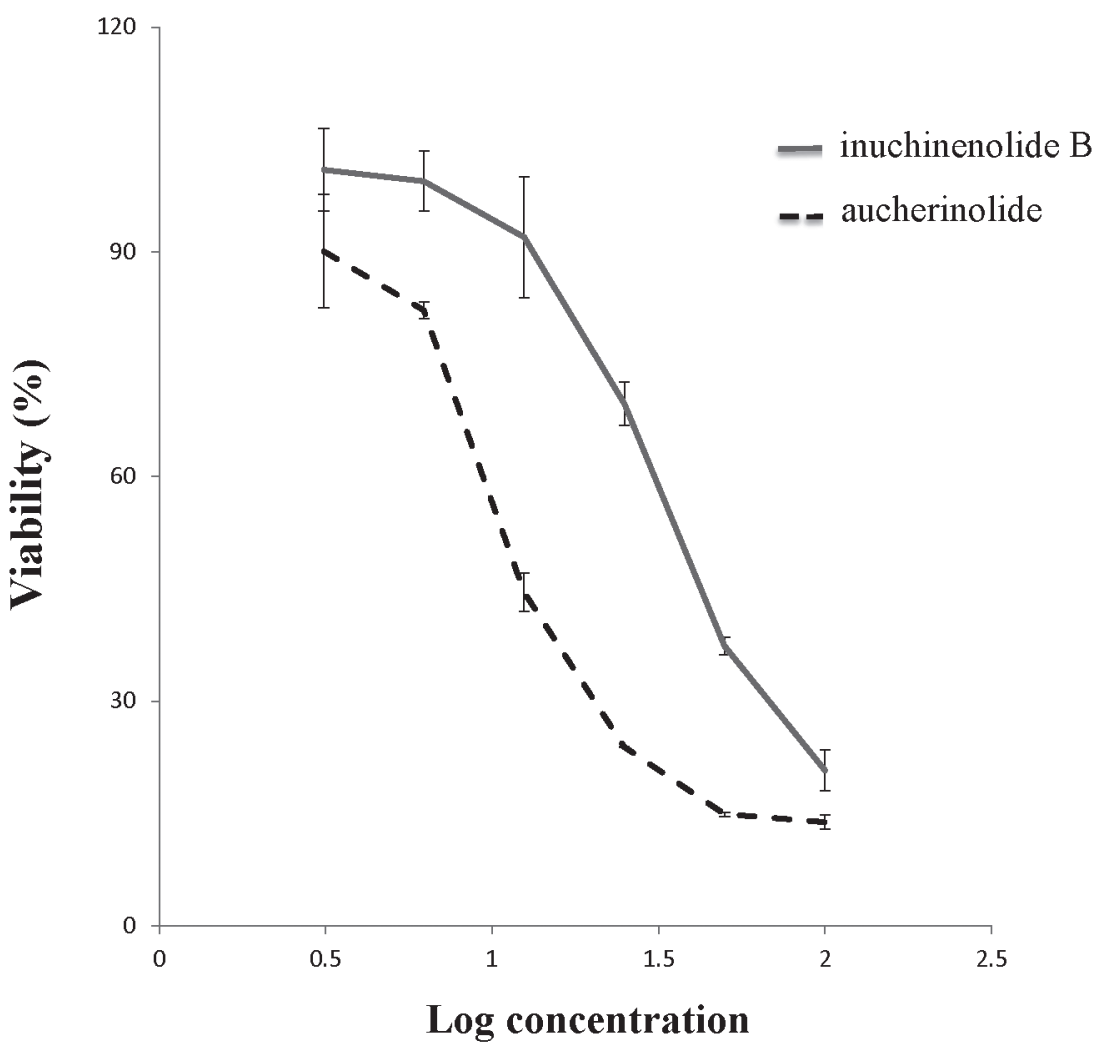

Figure 5 - Viability of inuchinenolide B and aucherinolide in MCF-7 cells. Values represent the mean $\pm \mathrm{SD}$ of 3 separate experiments. 
TABLE III

IC $_{50}$ values for inuchinenolide $B$ and aucherinolide in cell lines.

\begin{tabular}{lccc}
\hline & \multicolumn{3}{c}{$\mathbf{I C}_{\mathbf{5 0}} \boldsymbol{\mu g} / \mathbf{m L}$} \\
\hline & HepG-2 & A-549 & MCF-7 \\
inuchinenolide B & 56.6 & 55.7 & 39.0 \\
aucherinolide & 19.0 & 15.3 & 11.8 \\
\hline
\end{tabular}

five sesquiterpene lactones isolated from flowers of Tanacetum vulgare against A-549 cells to be 15.3-59.4 $\mu \mathrm{M}$ (Rosselli et al. 2012). Considering the outcomes of the present study, $\mathrm{IC}_{50}$ values of inuchinenolide B seemed rather high; however, the results of MTT assay for aucherinolide were comparable with some published reports about the in vitro toxcicity of sesquiterpene lactones mentioned above.

\section{CONCLUSIONS}

As mentioned earlier there are several reports about the cytotoxicity and apoptotic inducing properties of sesquiterpene lactones of the genus Inula. The sesquiterpene lactones of the present study, especially the two that have demonstrated cytotoxic activity somewhat explain the previously reported cytotoxicity demonstrated by extracts of Inula aucheriana. These compounds might execute their cytotoxic properties through apoptotic induction; however, this assumption needs further investigations about the molecular mechanisms of their cytotoxic activity.

\section{ACKNOWLEDGMENTS}

The project was granted by Traditional Medicine and Materia Medica Research Center (TMRC), Shahid Beheshti University of Medical Sciences (Grant No. 118). The authors also express their gratitude to Mr. Hamid Moazzeni, (TMRC) for assistance in collecting the plant. Mass spectrometric analysis for this work was carried out at the Bioanalytical Mass Spectrometry Facility, UNSW.

\section{RESUMO}

Inula aucheriana DC, uma espécie da família Asteraceae, é conhecida pela produção de lactonas sesquiterpênicas que são metabólitos secundários cititóxicos. No presente estudo, as seguintes lactonas sesquiterpênicas foram isoladas de I. aucheriana: inuchinenolida B, 6-desoxichamissonolida (estevina) e 14-acetoxi-1 $\beta, 5 \alpha, 7 \alpha H$-4 $\beta$-hidroxi-guai-9(10, 11(13)-dien12,8 $\alpha$-olida. A atividade citotóxica da inuchinenolida $\mathrm{B}$ e da 14-acetoxi-1 $\beta, 5 \alpha, 7 \alpha H$-4 $\beta$-hidroxi-guai-9(10),11(13)dien-12,8 $\alpha$-olida foi avaliada pelo ensaio do MTT (brometo de 3-(4,5 dimetiltiazol-2il)-2,5- difeniltetrazólio) em culturas de células HepG-2, MCF-7 e A-549 tendo sido determinados valores de IC50 de (56.6, $19.0 \mu \mathrm{g} / \mathrm{mL}),(39.0,11.8 \mu \mathrm{g} / \mathrm{mL})$, e $(55.7,15.3 \mu \mathrm{g} /$ $\mathrm{mL})$, respectivamente. A atividade citotóxica das duas lactonas sesquiterpênicas avaliadas explica a atividade citotóxica previamente observada para os extratos de Inula aucheriana. As substâncias isoladas merecem ser investigadas em estudos direcionados para pesquisas em câncer.

Palavras-chave: citotoxicidade, Inula aucheriana, ensaio do MTT, lactonas sesquiterpênicas.

\section{REFERENCES}

Bown D. 2002. Encyclopedia of Herbs and Their Uses. London: Dorling Kindersley.

Chen CN, Huang HH, Wu CL, Lin CP, Hsu JT, Hsieh HP, ChuANG SE AND LAI GM. 2007. Isocostunolide, a sesquiterpene lactone, induces mitochondrial membrane depolarization and caspasedependent apoptosis in human melanoma cells. Cancer Lett 246(1-2): 237-252.

Cheng XR, Li WW, Ren J, Zeng Q, Zhang SD, Shen YH, YAN SK, YE J, JiN HZ AND ZHANG WD. 2012. Sesquiterpene Lactones from Inula hookeri. Planta Med 78(5): 465-471.

FANG XM, LiU B, LIU Y, WANG JJ, Wen JK, Li BH AND HAN M. 2011. Acetylbritannilactone suppresses growth via upregulation of krüppel-like transcription factor 4 expression in HT-29 colorectal cancer cells. Oncol Rep 26(5): 1181-1187.

Hamzeloo-Moghadam M, Hajimehdipoor H, Saiednia S, Atoofi A, Shahrestani R, ReAd RW AND MosadDEGH M. 2012. Anti-proliferative Activity and Apoptotic Potential of Britannin, a Sesquiterpene Lactone from Inula aucheriana. Nat Prod Commun 7(8): 979-980. 
Hamzeloo-Moghadam M, Naghibi F, Atoofi A, Asgharian REZAIE M, IRANI M AND MosadDEGH M. 2013. Cytotoxic Activity and Apoptosis Induction by Gaillardin. Z Naturforsch 68c: 108-112.

ITO K AND IIDA T. 1981. Seven sesquiterpene lactones from Inula britannica var. chinensis Phytochem 20: 271-273.

KABEer FA, SREEDEVI GB, NAIR MS, RAJALEKSHMI DS, GOPALAKRISHNAN LP, KUNJURAMAN S AND PRATHAPAN R. 2013. Antineoplastic effects of deoxyelephantopin, a sesquiterpene lactone from Elephantopus scaber, on lung adenocarcinoma (A549) cells. J Integr Med 11(4): 269-277.

Lee J, Hwangbo C, Lee JJ, Seo J AND LeE JH. 2010. The sesquiterpene lactone eupatolide sensitizes breast cancer cells to TRAIL through down-regulation of c- FLIP expression. Oncol Rep 23(1): 229-237.

LiU B, HAN M, SUN RH, WANG JJ, LIU YP AND WEN JK. 2011. Acetylbritannilactone induces G1 arrest and apoptosis in vascular smooth muscle cells. Int J Cardiol 149(1): 30-38.

LiU S, LiU H, YAN W, Zhang L, Bai N AND Ho CT. 2005. Design, synthesis, and anti-tumor activity of (2-Oalkyloxime-3phenyl)-propionyl-1-Oacetylbritannilactone esters. Bioorg Med Chem 13(8): 2783-2789.

Mosaddegh M, Hamzeloo-Moghadam M, Ghafari S, NAGHIBI F, OSTAD SN AND READ RW. 2010. Sesquiterpene lactones from Inula oculus-christi. Nat Prod Commun 5(4): 511-514.

Mosaddegh M, Ostad SN, Naghibi F AND HamzelooMoghadam M. 2006. Cytotoxic effects of five species of Inula against some tumor cell lines. Iranian J Pharmaceut Sci 2: 203-208.

PAN MH, ChIOU YS, CHENG AC, BAI N, LO CY, TAN D AND Ho CT. 2007. Involvement of MAPK, Bcl-2 family, cytochrome $\mathrm{c}$, and caspases in induction of apoptosis by 1,6 Odiacetylbritannilactone in human leukemia cells. Mol Nutr Food Res 51(2): 229-238.

Popović V, Heyerick A, Petrović S, VAn CAlenbergh S, Karalić I, Niketić M AND Deforce D. 2013. Sesquiterpene lactones from the extracts of two Balkan endemic Laserpitium species and their cytotoxic activity. Phytochemistry 87: 102-111.
QIN JJ, JIN HZ, FU JJ, HU XJ, WANG Y, YAN SK AND ZHANG WD. 2009. Japonicones A-D, bioactive dimeric sesquiterpenes from Inula japonica Thunb. Bioorg Med Chem Lett 19(3): 710-713.

QIN JJ, Jin HZ, HUANG Y, ZHANG SD, SHAN L, VORUGANTI S, NAG S, WANG W, ZHANG WD AND ZHANG R. 2013. Selective cytotoxicity, inhibition of cell cycle progression, and induction of apoptosis in human breast cancer cells by sesquiterpenoids from Inula lineariifolia Turcz. Eur J Med Chem 68: 473-481.

Rosselli S, BRUno M, RAIMONDO FM, SPADARO V, VAROL M, Koparal AT and Maggio A. 2012. Cytotoxic Effect of Eudesmanolides Isolated from Flowers of Tanacetum vulgare ssp. Siculum Molecules 17: 8186-8195

SECAAM, Grigore A, PINTO DCAND SILVA AM. 2014. The genus Inula and their metabolites: from ethnopharmacological to medicinal uses. J Ethnopharmacol 154(2): 286-310.

SONG YJ, LEE DY, KIM SN, LEE KR, LEE HW, HAN JW, KANG DW, LEE HY AND KIM YK. 2005. Apoptotic potential of sesquiterpene lactone ergolide through the inhibition of NF-kappaB signaling pathway. J Pharm Pharmacol 57(12): 1591-1597.

Willuhn G, Pretzsch G And Wendisch D. 1981. Zwei neue pseudoguaianolide aus den blüten von Arnica chamissonis less. Subsp. Genuina Maguire. Tetrahedron 37: 773-776.

Xie HG, Chen H, CAO B, Zhang HW and Zou ZM. 2007. Cytotoxic Germacranolide Sesquiterpene from Inula cappa. Chem Pharm Bull 55(8): 1258-1260.

Zeng GZ, TAN NH, Ji CJ, FAN JT, HuANG HQ, HAN HJ AND ZHOU GB. 2009. Apoptosis inducement of bigelovin from Inula helianthus-aquatica on human Leukemia U937 cells. Phytother Res 23(6): 885-891.

ZhaO YM, Zhang ML, SHI QW AND KiYota H. 2006. Chemical constituents of plants from the genus Inula. Chem Biodivers 3(4): 371-384. 
